\title{
ПЕРЕЧИТЫВАЯ КЛАССИКУ
}

DOI $10.37386 / 2305-4077-2021-1-67-80$

\section{О. Б. Заславский ${ }^{1}$ \\ Харьковский начиональный университет им. В. Н. Каразина \\ О НЕОПРЕДЕЛЕННОСТИ КАК СТРУКТУРНОМ СВОЙСТВЕ «ТАМАНИ»}

Художественному миру «Тамани» свойственна неопределенность. Это проявляет себя на самых разных структурных уровнях текста - в сюжете, построении фразы, композиции, особенностях художественного пространства. В частности, учет этого обстоятельства позволяет понять, почему в тексте упомянут микросюжет о смерти от голода, оставшийся без продолжения. Наряду с этим, в произведении действует и противоположная тенденция, в которой становятся актуальными такие понятия, как предел и граница, а также другие дискретные характеристики (в частности, различные структурные оппозиции). В свою очередь, эта тенденция расшатывается, а определенность границы подрывается, дискретные характеристики размываются. Тем самым интуитивно ощущаемая читателями атмосфера таинственности получает частичное объяснение в терминах особенностей структуры текста.

Ключевые слова: граница, сюжет, двусмысленность

\section{O. B. Zaslavskii}

\section{N. Karazin Kharkov National University}

\section{ON UNCERTAINTY AS A STRUCTURAL PROPERTY OF "TAMAN"}

Ambiguity is one of key features of artistic world of "Taman". It is manifested on different structural levels of the text, including the plot, the construction of phrases, composition, and the peculiarities of artistic space. In particular, taking into account this circumstance enables us to understand why a micro-plot about death from hanger (left without continuation) is mentioned in the text. Along with this, there is also an opposite tendency in the text in which such notions as a limit and boundary are actualized as well as other discrete characteristics (for example, various structural oppositions). Thus, the atmosphere of mystery (perceived by readers on an intuitive level) acquires partial explanation in terms of peculiarities inherent to the structure of the text.

Key words: boundary, plot, ambiguity

\section{Введение}

Одним из характерных свойств «Тамани» является структурная неопределенность, которая состоит в двузначности ряда дискретных элементов, их смазывании, а также сосуществовании дискретного и непрерывного вариантов одного и того же. Эти свойства были рассмотрены нами в предыдущей работе [Заславский, 2008], в основном на уровне языка, фразы и слова. В данной работе мы продолжаем исследование этого феномена, расширяя объем наблюдений, а также перенося рассмотрение и на другие уровни, которые затрагивают художественное пространство, сюжетную логику и т.д.

${ }^{1}$ Олег Борисович Заславский, доктор физико-математических наук, ведущий научный сотрудник Харьковского национального университета им. В. Н. Каразина (Харьков). 
В частности, мы увидим, что характерным свойством «Тамани» является тенденция к размыванию границ. Создание полутонов вносит, в том числе, свой вклад и в общую атмосферу таинственности, где толком ничего не получает окончательных очертаний. Тем самым атмосфера таинственности, интуитивно ощущаемая при чтении «Тамани», хотя бы отчасти получает описание на языке структурного анализа. В какой-то степени, такая атмосфера связана с жанровой неопределенностью: произведению свойственны некоторые черты баллады, связанные прежде всего с взаимопроникновением миров [Козубовская, 2014]. Однако нас будет главным образом интересовать, как это проявляет себя во внутренней структуре текста. Кроме того, элементы смешения жанров (прозаической повести и баллады) сами по себе являются примером неопределенности, которая, как мы увидим, является характерным свойством данного произведения.

\section{Первый абзац и структура целого}

Миру «Тамани» свойственна борьба двух структурных тенденций стремления к созданию определенности и ее разрушению. Соответственно, присутствует значимость таких категорий, как граница и предел. Именно на таком фоне и становится заметной их размазанность или неполная реализация. Отчасти значимость границы мотивирована сюжетом: персонажи (контрабандисты) занимаются деятельностью, которая как раз связана с незаконным пересечением границы и (или) перемещением через нее товаров. Однако дело этим не исчерпывается. Вышеупомянутые категории деавтоматизуются и пронизывают весь текст, в том числе возникая в довольно неожиданных местах. Ниже мы увидим, что в произведении постоянно возникает контраст между двумя пространствами или состояниями, которые эта граница разделяет. В пользу значимости указанных структурных свойств говорит то, что они с повышенной концентрацией присутствуют в первом же (а тем самым структурно выделенном) абзаце. Рассмотрим это подробнее.

Пограничный характер ситуации обнаруживается уже в первой же фразе «Тамани». Тамань оценивается как приморский город, т.е. элемент суши, находящийся около воды. Тамань находится на побережье Таманского залива в акватории Керченского пролива, причем через этот пролив проходит граница между Европой и Азией. Данный город называется самым скверным (из множества таких городов), т.е. указывается предельная степень качества. Во второй фразе «Я там чуть-чуть не умер с голоду, да еще вдобавок меня хотели утопить» [Лермонтов, 1957, т. 6, с. 249]2 указан крайний (хотя и не достигнутый) предел жизни - смерть. Причем это обстоятельство удвоено: мало того, что герой сам подошел вплотную к опасному пределу, так его еще специально хотели убить. К месту назначения герой прибыл «поздно ночью»,

\footnotetext{
${ }^{2}$ Роман М. Ю. Лермонтова цитируется по: Лермонтов, М. Ю. Сочинения: в 6 т. Т. 6. Проза, письма.-М.; Л.: Изд-во АН СССР, 1957. Далее номер страницы указывается в круглых скобках после цитаты. 
т. е. на границе обоих дней - уходящего и наступающего: «Ямщик остановил усталую тройку у ворот единственного каменного дома, что при въезде» (с. 249). Здесь исключительность объекта сочетается с его пограничным положением. Причем твердый каменный дом составляет контраст с водой субстанцией, в которой едва не утопили Печорина. Далее часовой «закричал спросонья диким голосом: «кто идет?» (с. 249), т.е. часовой, еще не вполне проснувшийся, но уже приступивший к исполнению своих обязанностей, находился и действовал как раз на границе сна и бодрствования. Причем этот часовой (черноморский казак) обладает двойным статусом, имея отношение и к Черному морю, и к казачеству (т. е. объектам, связанным с водой и сушей). Вскоре герой пытается найти квартиру: оказывается, что все заняты, кроме одной (т.е. опять выделяется исключительный элемент на общем фоне. Ср. с Таманью в 1-й фразе). В поисках квартиры Печорин и десятник подъехали «к небольшой хате, на самом берегу моря», т.е. находящейся на границе. Пограничность усилена: «на дворе, обведенном оградой из булыжника, стояла избочась другая лачужка, менее и древнее первой. Берег обрывом спускался к морю почти у самых стен ее» (с. 250). Здесь берег, т. е. граница между морем и сушей, подступает к самой лачужке.

В данном контексте также значимо и то, что фрагмент со столь высокой концентрацией элементов, связанных с границей и пределом, возникает именно в 1-м абзаце, т. к. абзаце, который лежит на границе текста.

По наблюдению А. К. Жолковского, «особенность «Тамани» именно в том, что до предела в ней ничего не доводится. (...) Событийные ружья не стреляют» [Жолковский, 1992, с. 254]. Однако, с другой стороны, важно, что само понятие предела оказывается значимым, и не только в отношении сюжета. В частности, это касается художественного пространства и времени.

\section{Граница и ее смазывание}

Одной из реализаций границы является граница между водой и сушей, примеры чего приведены выше. В более общем случае можно указать на противопоставление твердости и текучей субстанции, а также на контраст отдельного, дискретного элемента и окружающей его сплошной среды. В частности, это касается чужеродности Печорина окружающему его миру, противоречивости их сочетания. В конце повести Печорин сам сравнивает себя с камнем, брошенным в «гладкий источник». В предшествующих событиях его пытались убить, причем сбросив с лодки. Можно думать, что неумение Печорина плавать - это как раз одно из проявлений его чужеродности по отношению к окружающей среде [Савинков, 2004, с. 238]. В этом смысле фамилия героя, указывающая на реальную реку, является знаком неустранимого внутреннего противоречия между именем (т.е., на мифопоэтическом языке, сущностью героя [Топоров, 1987]) и его реальным бытием. В частности, он противопоставлен ундине, для которой вода является своей стихией; сражение между ними затрагивает противопоставление участка суши (реализацией которого является лодка) и воды. 
Однако вода не только противопоставлена чему-то, ей противоположному; присущая ей текучесть также захватывает связанные с ней другие сущности, а противопоставление может превращаться в создание единого целого, в котором эти противопоставления сглажены, а граница - смазана. Так, про дочь хозяйки мальчик говорит, что она «утикла». Каламбурным образом это украинское слово, означающее «убежала», указывает на процесс, происходящий с водой. Причем татарин, с которым она убежала,- лодочник, т.е. его профессия тоже связана с водой.

Смазывание контрастов проявляет себя, в частности, в том, что вода сопоставляется с огнем, причем таким образом, что вместо прямого противопоставления противоположных, казалось бы, стихий, они переплетаются в единое целое, продолжая друг друга. Как только Печорин отворил дверь в хату, оттуда «повеяло сыростью» (с. 250). Сразу после этого он «засветил серную спичку» (c. 250). Печорин входит внутрь и замечает, что «в разбитое стекло врывался морской ветер» (с. 251), т.е. вода как бы проникает и сюда. Сразу вслед за этим говорится: «Я вытащил из чемодана восковой огарок» (с. 251). На небольшом пространстве текста появление огня и света не только происходит как реакция на темноту, с одной стороны, с другой огонь и свет дважды сочетаются с водой (сыростью).

Уже после того, как в доме появляются старуха и ундина, упоминается, что герой приказал денщику нагреть чайник. Но в этой процедуре участвуют огонь и вода, причем не как противоположные друг другу элементы, а составляющие единое целое. Появляется ундина. Назначив ему свидание, она убегает: «в сенях она опрокинула чайник и свечу, стоявшую на полу» (с. 257). Чайник, очевидно, уже не был на огне, поскольку чай был готов: сам Печорин «доканчивал второй стакан чаю», и он также «готов был прервать молчание самым прозаическим образом, то есть предложить ей стакан чаю» (с. 257). Тем самым объединение огня и воды здесь стало неактуальным. Но оно восстанавливается благодаря упомянутой свече: чайник здесь связан с водой, а свеча - с огнем.

Далее, уже на самом «свидании», когда герои оказываются в лодке, девушка в решающий момент бросает в воду пистолет, т.е. огнестрельное оружие, а потом пытается столкнуть туда же самого Печорина. Вновь условно объединяются, а не противопоставляются вода и огонь - и то и другое выступает здесь как смертоносное оружие, причем и то и другое так и не срабатывает по назначению.

Тем самым роль воды оказывается двойственной: вода как участвует в создании и реализации контрастов, так и захватывает своей текучестью ту часть мира, которая, казалось бы, должна составлять ей контраст.

Смазывание границы, текучесть относится также к месту действия Тамани. Тогда Тамань была казачьей станицей [Дурылин, 1940, с. 207], и лишь с натяжкой может быть названа городом. Неслучайно в тексте она фигурирует с названием «городишко», причем в описании подчеркивается его деревенский вид. Таким образом, Тамань - это место, где различие, граница между городом и селом стерты, так что статус места оказывается не вполне неопределенным. 
Имя «Печорин», как заметила Силади, связано одновременно и с водой (Печора), и с огнем (печь) [Силади, 1994, с. 22], [Силади, 2014, с. 618-619]. Но дело здесь не только в имени как таковом, а и в развертывании соответствующего дуализма в самом тексте. Там встречается фраза «Печь была жарко натоплена» (c. 254). Глагол «топить» означает два противоположных действия. Можно разводить огонь и топить печь (как это сделано в доме, где живут девушка и старуха), а можно топить в воде, что и попыталась позднее сделать ундина. Тем самым и здесь в тексте присутствует слово с двойным (неопределенным) значением, которое конкретизуется только в том или ином контексте.

\section{Несостоявшаяся смерть от голода}

Фрагмент о печи интересен еще и в другом отношении. Одно из загадочных мест «Тамани» - это упоминание в самом начале о том, что герой едва не умер от голода. Далее мотив голода повисает практически без продолжения. (Что касается еды, то лишь упоминается обед, который готовится в печи, своей роскошью не слишком подходящий для бедняков.) Делалась попытка (на наш взгляд, искусственная) трактовать отмеченную аномалию как связь между особенностями повествования и настроением повествователя ${ }^{3}$.

Однако, думается, дело здесь совсем в другом. Сюжет о голоде, оставшийся без продолжения, является примером неудовлетворенной двойной потребности - в пище физической (для героя) и в пище духовной (для читателя). Тем самым, сюжетный обрыв линии, связанной с голодом, является иконическим воспроизведением самого мотива голода. В этом отношении здесь можно видеть аналогию с явлением псевдооборванного текста, когда сюжет обрывается, но сам обрыв тематизируется, будучи воплощением актуальных для произведения тем (смерти, конца и т.п.) [Заславский, 2006]. Разница между данным конкретным случаем и теми, что были рассмотрены в вышеупомянутой работе, состоит в том, что в псевдооборванном тексте обрыв происходит в конце материально зафиксированного текста. Здесь же - в его толще, точнее - даже в начале, а вместо категории конца как такового релевантна нехватка (хотя и обрыв можно рассматривать как нехватку дальнейшего текста). В общем и целом, такой мотив нехватки как раз и является одним из проявлений колеблющейся неопределенности произведения, того обстоятельства, что в нем ничего толком не происходит окончательно [Жолковский, 1992, с. 254].

Кроме того, упоминание о смерти от голода (не состоявшейся) на фоне печи с роскошным обедом, который там готовился, вводит мотив танталовых мук. Это же относится и к пище духовной: читатель хочет наконец прочитать про чуть не состоявшуюся смерть от голода, но это никак не удается.

3 «Подобная неувязка уже в «экспозиции»- - ннак импульсивной, импровизационной природы повествования, синхронно запечатлевающего - на протяжении всей «Тамани» - непредсказуемые перепады настроения самого героя-повествователя [Ломинадзе, 1989, с. 323]. 
Содержательный аспект описанного приема связан с темой произведения в целом. Поскольку его сюжет связан с попыткой повествователя «достать ключ этой загадки» (с. 254), не доведенный до конца микро-сюжет структурно воспроизводит основную коллизию повествования и вносит своей неопределенностью вклад в создание атмосферы таинственности.

\section{Персонажи: неопределенность идентификации}

Одним из значимых в повести свойств воды, как указанное выше, является ослабление, смазывание противоположностей, что способствует созданию неопределенности как общего структурного свойства. Это явление затрагивает и персонажей. Сначала о мальчике говорится «Он был слепой, совершенно слепой от природы» (с. 250). Но затем сообщается: «В голове моей родилось подозрение, что этот слепой не так слеп, как оно кажется; напрасно я старался уверить себя, что бельмы подделать невозможно, да и с какой целью? Но что делать? Я часто склонен к предубеждениям...» (с. 251). Вскоре Печорин смог удостовериться, что слепой легко спустился с узлом по крутой тропинке, хотя сам Печорин сделал это с трудом, что скорее говорит об обоснованности сомнений. В дальнейшем сомнение в слепоте вновь актуализуется в словах казака: «что это за слепой! ходит везде один, и на базар за хлебом, и за водой» (c. 254). Однако затем, в разговоре контрабандистов, звучит слово «слепой», да и появление лодки Янко он определяет лишь по слуху. То обстоятельство, что это - действительно слепой, тем самым получает подтверждение, однако тем более остаются значимыми сомнения в его слепоте, которые посещают Печорина и его денщика,- именно потому, что их рациональная основа подрывается. Таким образом, сначала о слепоте сообщается совершенно определенным образом как о достоверном факте. Затем эта определенность ставится под сомнение. Однако сам этот подрыв достоверности тоже оказывается не вполне определенным и смазывается.

Слепой мальчик упоминает дочь хозяйки, которая «была», да «утикла» с лодочником - татарином. Слово «была» становится двусмысленным: то ли дочь у старухи есть, но находится далеко, то ли она после бегства как бы вообще перестает существовать в таком качестве. Эта двусмысленность усиливается далее. На следующий день казак говорит Печорину: «Сегодня без вас пришла старуха и с ней дочь». Печорин возражает: «Какая дочь? у ней нет дочери» (c. 254). Кроме того, его фраза вообще является двусмысленной: то ли он имеет в виду, что дочь покинула старуху, то ли что у старухи ее никогда и не было.

Есть объективные аргументы в пользу того, что ундина не является дочерью старухи, однако они не вполне однозначны. С одной стороны, об этом свидетельствует несоответствие возрастов: про ундину сообщается, что ей «казалось не более 18 лет», а про старуху Янко в конце говорит, что она «зажилась», и ей «пора умирать». С другой стороны, слова слепого про старуху «побигла в слободку» не очень сочетаются с почтенным возрастом действительно ли хозяйка является старухой? 
Фраза слепого про дочь и крымского татарина также остается неясной. Значит ли это, что у хозяйки действительно есть дочь, но это не та девушка, что участвует в событиях (раз «утикла»)? Тогда, видимо, и «крымский татарин» и Янко это разные лица? И можно ли вообще полагаться на точность информации от этого мальчика?

Что касается правомерности отождествления татарина (лодочника из Керчи) и Янко, то даже самый внешний вид Янко подрывает здесь определенность. Хотя Янко носит татарскую шапку, при этом он острижен по-казацки, а имя у него - не татарское. Причем не вполне ясно, как под шапкой можно было разглядеть стрижку.

Дело обстоит таким образом, что в описании статуса персонажей остаются неустранимые двусмысленности, намекающие на неокончательность идентификации.

В эту игру полутонами включается и оценка со стороны повествователя. Он сравнивает героиню с русалкой. Но русалка - существо двойной природы, которое сочетает воду и сушу, жизнь и смерть, человеческое и рыбье. Про героиню говорится: «она, как змея, скользнула между моими руками» (с. 257), упоминается ее «змеиная натура» (с. 258). Поскольку существуют водоплавающие змеи, здесь объединяются вода и суша.

Печорин узнает имя только одного контрабандиста - Янко (из разговоров контрабандистов). Однако имена девушки и слепого мальчика остаются ему (и читателю) неизвестными. Кроме того, Печорин не слышит имени еще одного участника (заказчика?), о котором говорит Янко. Это тем более значимо, что практически все остальное Печорин слышит. А поскольку человек мифопоэтически представляет свое имя [Топоров, 1987], то получается, что таинственность захватывает самих людей.

Делались попытки [Силади, 1994, с. 26], [Силади, 2014, с. 619] объяснить имя Янко в данном контексте ${ }^{4}$. Мы полагаем, что это неверный подход. Здесь значимо не то, чем является это имя, а то, что у него нет определенной культурной принадлежности. В повести пересекаются 3 культуры - русская, украинская, татарская. Однако Янко - это имя, которое не принадлежит ни одной из них.

Еще одно проявление несогласованности, отсутствия определенности - это способ идентификации контрабандистов. Персонажи, входящие в их компанию, характеризуются по разным критериям. В случае Янко - это имя, с девушкой связаны литературные параллели, для слепого - это физический изъян, для старухи - это возраст.

Ранее нам уже приходилось отмечать, что двойной смысл слова «нечисто» (грязь или связь с нечистой силой) может рассматриваться как пример языковой неопределенности [Заславский, 2008, с. 77]. Это наблюдение можно усилить, так как сюда подключается и третий смысл слова, связанный с «нечистыми» делами «людей недобрых», т.е. разбойников [Кривонос, 2019, с. 42].

\footnotetext{
${ }^{4}$ В частности, Силади пыталась увязать часть имени «ян» с наименованием «водяной». Это представляется нам недостаточным для надежного анаграммирования. Кроме того, анаграммируются обычно выделенные, ключевые слова, а «водяной» таким словом в произведении не является.
} 


\section{Неопределенность в построении фразы}

В тексте «использована весьма нетривиальная стилистическая фигура» [Мильчина, 2015, с. 567]: «Она, то есть порода, а не Юная Франция...» (с. 256). Мильчина указывает французский источник такого построения - новеллу Т. Готье «Пуншевая чаша». Однако нас сейчас интересует не вопрос, откуда это попало в текст Лермонтова, а какую роль это играет в системе целого. Нетрудно видеть, что в «Тамани» здесь специально сделана оговорка, чтобы нейтрализовать двусмысленность - характерное свойство «Тамани», которые мы имели возможность обнаружить в целом ряде других случаев. При этом получается характерное для произведения столкновение обоих структурных принципов - смазывания и стремления к прояснению.

\section{Неопределенность в сюжете}

Неопределенность, окружающая персонажей, тянет за собой и неопределенность в сюжете. Слепой говорит рассказчику, что дочь хозяйки убежала с лодочником-татарином. Приведем интерпретацию, предложенную Силади: «Слепой способен предвидеть будущее: он лишён внешнего зрения, но у него особенно развито зрение внутреннее. О дочери хозяина он говорит: „... утикла за море с татарином”. В конце главы девушка (которая в тексте один раз отождествляется с дочерью хозяйки: „кто она, коли не дочь”) действительно „тикает” за море с Янко, который носит татарскую баранью шапку. Значит, в конце главы происходит то, о чём слепой говорит в начале» [Силади, 1994, с. 24].

Такая интерпретация представляется нам чересчур буквальной и прямолинейной, она также не вполне согласуется с текстом. Факт побега дочери (о чем упоминает слепой) относится к прошлому, здесь нет никакого предвидения, это просто изложение уже состоявшихся событий. Однако этот факт действительно соотносится с будущим. Только здесь проявляет себя скорее не какая-то особая способность персонажа, а свойство структуры текста - наличие профетического элемента в сюжете как таковом [Славутин, 2018, с. 42-58]. Однако здесь ситуация усложнена тем, что неясно, относится ли сопоставление к тем же самым элементам (персонажам) или другим. То ли дочь сбегает во 2-й раз (причем с тем же самым спутником), то ли другие персонажи повторяют 1-й эпизод. Здесь проявляет себя ключевое свойство «Тамани», связанноеименно со смазанностью, неоднозначностью и неопределенностью, а вовсе не четкое и буквальное соотнесение эпизодов.

\section{Янко и завершение сюжета}

Можно заметить, что, разговор, который ведет Янко в конце повести, сам по себе изобилует двусмысленностями. Он сообщает слепому, что больше не будет работать на нынешнего работодателя. При этом он сразу, одно за другим, выдвигает два совершенно разных объяснения. С одной стороны, «теперь опасно», с другой - «кабы он получше платил за труды, так и Янко бы его не покинул» (с. 259). Мотивировка раздваивается, но здесь по крайней мере нет прямого противоречия (можно представить, что за повышенную плату Янко готов бы был рискнуть). Гораздо труднее примирить другие два высказывания того же персонажа: «теперь опасно» и «поеду искать работы в другом месте, а ему уж такого удальца не найти». Казалось бы, удалец именно на то и удалец, что готов пренебречь опасностью. 
Янко специально останавливается на судьбе старухи: «старухе скажи, что, дескать, пора умирать, зажилась, надо знать и честь» (с. 259). Можно думать, что вероятность смерти для старухи резко возрастает из-за того, что девушка не будет больше заботиться о ней, а дохода от контрабанды старуха лишится. Обе эти причины связаны с Янко, его решением увезти девушку и оставить работу в этих краях; они имеют практический характер. Вместо этого Янко ссылается на универсальные свойства бытия. Тем самым смысл мотивировки раздваивается. Также выглядит странным, что именно сейчас старуха (принимавшая, очевидно, какое-то участие в деятельности контрабандистов) вдруг оказалась подвержена внезапной старости. В результате получается наложение двух типов причин ожидаемой смерти старухи, т.е. и здесь проявляет себя неопределенность.

В 1-м разделе мы уже говорили о том, что начало повести (1-й абзац) насыщено предельными ситуациями. Но это же свойство проявляет себя и здесь. Ведь слова Янко про старуху «зажилась» означают, что, по его мнению, старуха перешла через положенный предел. Однако сам этот переход, как мы старались обосновать это выше, связан с целым рядом неопределенностей.

\section{Последний абзац и граница текста}

Рассмотримпоследнеепредложениеповести: «Даикакоеделомнедорадостей и бедствий человеческих, мне, странствующему офицеру, да еще с подорожной по казенной надобности!..» (с. 260). Здесь заявляется противопоставление радостей и бедствий. Однако сказанное о старухе и слепом в предшествующем тексте (Янко уезжает, бросая их на произвол судьбы) не оставляет никаких сомнений, что речь может идти только о бедствиях, радостей же и близко не ожидается. Тем самым однозначная ситуация представлена как двузначная, с порождением неопределенности. В целом же фраза про радости и бедствия, благодаря эпитету «человеческих», ставит героя в позицию вненаходимости. Он как бы наблюдает над человечеством снаружи, тем самым превращаясь то ли в бога, то ли в демона. Однако ссылка на «странствующего офицера», подорожную и казенную надобность сразу же спускает этот образ, так сказать, с небес на землю. В результате получается двойной образ - человека (причем зависимого) и сакральной сущности.

Таким образом, в самом конце произведения вновь проявляет себя художественная игра между однозначностью и двузначностью (или неопределенностью). Причем однозначное превращается здесь в двойное.

Обратим теперь внимание на предпоследнее предложение: «Что сталось с старухой и с бедным слепым - не знаю» (с. 260). Само по себе, такое упоминание повествователя после рассказа о событиях не является чем-то особенным. Однако дело в том, что сразу после окончания текста «Тамани» следует надпись «Конец первой части». Это означает, что описание событий и дальнейшая информация о двух персонажах (точнее, отсутствие конкретных сведений) оказываются лежащими по разные стороны от границы текста.

Указанная надпись также акцентирует, что данная повесть является последней в 1-й части романа. То есть она находится в предельной точке, что вновь реализует тему предела и границы. 


\section{Зрение и слух, внутреннее и внешнее}

Печорин замечает «я начал рассматривать лицо слепого; но что прикажете прочитать на лице, у которого нет глаз?» (с. 251). Здесь Печорин упоминает процесс, в котором он сам является наблюдателем (субъектом наблюдения), а мальчик - наблюдаемым (объектом наблюдения). Однако критерием для прочтения выставлена ссылка на наличие (или отсутствие) у наблюдаемого органа наблюдения, которое превращает его из объекта наблюдения в субъект; соответственно, Печорин был бы его объектом. Упрощая, слова Печорина можно передать так: «разве можно увидеть невидящий объект?». Такое сочетание весьма нетривиально и отличается от стандартного варианта «разве можно увидеть невидимый объект?». Здесь происходит инверсия субъекта и объекта, взгляда снаружи на объект и обратного взгляда из самого объекта, внешнего и внутреннего. Можно сказать, что здесь граница между такими категориями упразднена, они переходят одна в другую.

Далее, когда Печорин следит за мальчиком, в его мыслях возникает искаженная цитата из Библии «В тот день немые возопиют и слепые прозрят» (c. 251). Тут, как неоднократно отмечалось в литературе, имеется в виду книга пророка Исайи. А именно, в книге пророка Исайи 29, 18 сказано (в синодальном переводе): «И в тот день глухие услышат слова книги, и прозрят из тьмы и мрака глаза слепых». Далее, в Исайя 35, 4: «Тогда откроются глаза слепых, и уши глухих отверзутся» ${ }^{5}$. Здесь в «Тамани» субъект зрения смазывается, поскольку не вполне ясно, к кому же относится «прозрение»,- к мальчику, уверенно идущему (как зрячий) по крутому склону, или Печорину, который пытается распутать загадку. В этом смысле Печорин сам хочет «прозреть», и во многом это ему удается 6 .

Инверсия субъекта и объекта, которая была отмечена выше по отношению к эпизоду, где Печорин впервые увидел слепого, происходит также и во фрагменте, где цитируется Библия. Только теперь она относится не к зрению, а к слуху / говорению: вместо прорезавшегося слуха Печорин мысленно говорит об обретении дара речи, т. е. слушающий (имевшийся в виду в Библии), превращается в говорящего.

Зрение и слух вновь связываются в эпизоде, когда Печорин рассказывает девушке о том, что видел накануне, а она ему отвечает: «Много видели, да мало знаете, а что знаете, так держите под замочком» (с. 257). Здесь Печорину недвусмысленно дают понять, что лучше оставаться «немым», так что вариант

\footnotetext{
${ }^{5}$ Кроме того, в Исайя 35, 5 сказано «язык немого будет петь». Но сопоставление зрения и слуха содержится лишь в двух первых примерах, которые в этом смысле только и релевантны в обсуждаемых сопоставлениях. Поэтому мы ограничимся только ими.

${ }^{6}$ В работе [Савинков, Соколова, 2014, с. 49] приводится сравнение «бельмы на глазах мальчика не делают его невидящим, а делают невидимым его внутреннее содержание, в определенном смысле аналогичное содержанию великой книги». Сравнение «внутреннего содержания» слепого мальчика с Библией представляется нам перебором. По нашему мнению, сопоставления здесь должны касаться не материальных объектов, а функциональных отношений между ними (видимый - невидимый, объект - субъект и т. П.).
} 
«возопить» отвергается. Здесь также происходит еще один вид инверсии [Заславский, 2008, с. 76] - между внешним и внутренним, поскольку Печорин собирался раздобыть ключ загадки (т.е. отпереть нечто), а ему советуют держать это внутри, под замком.

\section{Переход между мирами}

«Тамань» оказывается в ряду лермонтовских произведений, где речь идет о проникновении героя (или героини) в чуждый ему и опасный мир. Сюда же можно отнести «Штосс», «Русалку», «Морскую царевну». В «Штоссе» упоминается баллада Гете, в которой лесной царь забирает ребенка в свой мир,ребенок при этом погибает. Главный герой «Штосса» Лугин также оказывается перед действием фантастических сил, в мир которых, вероятно, ему предстоит попасть окончательно [Заславский, 2013]. В «Русалке» мертвый богатырь на дне уже оказывается в ином мире, где вечно длится его посмертное бытие. В «Морской царевне» царевич насильно вытаскивает царевну из моря на сушу в чуждый ей мир, где она и погибает. Во всех этих случаях есть персонаж, который пересекает (не по своей воле) границу между мирами однократно, и остается в новом мире, где и погибает.

В «Тамани» же ситуация иная. Смысл профессии персонажей контрабандистов состоит как раз в том, что они пересекают границу, для других запретную, обратимым образом. Печорин, проникая в их мир, нарушает уже их запреты, но при этом ему удается вернуться назад. В результате он разрушает их мир. Причем вред для профессиональной деятельности оказывается взаимным: Печорин лишает их возможности провозить товар, а они (посредством кражи его оружия) наносят ущерб ему как офицеру.

В этом смысле столкновение миров вредит (хотя в разной степени) обеим сторонам, но к необратимым последствиям не приводит и, в отличие от других упомянутых выше случаев, трагических последствий не имеет: «неудача остается именно не-удачей, не-событием, никоим образом не драматизируясь до катастрофы» [Жолковский, 1992, с. 254].

\section{Завершение сюжета о контрабандистах}

Печорину удалось достать «ключ этой загадки» (с. 254), но разгадка оказалась отнюдь не полной. Из-за того, что Печорин своими изысканиями невольно разрушил сложившийся мир контрабандистов, сюжет об их деятельности, казалось бы, исчерпан и завершен. Однако в разговоре, что слышит Печорин в конце повести, создаются новые элементы неясности, связанные как раз с их деятельностью: «ты береги то место... знаешь? там богатые товары... скажи (имени я не расслышал)» (с. 259). Имя, место и информация о товарах остаются Печорину (а вместе с ним и читателю) неизвестными, прояснение «загадки», интересовавшей Печорина, компенсируется в тексте новой неопределенностью. В цитированной выше фразе дважды употребляется многоточие. Но в самом конце повести появляется восклицательный знак (т. е. знак, связанный с сильным и определенным выражением эмоций). Однако, этот восклицательный знак, в свою 
очередь, сочетается с многоточием, т. е. знаком, указывающим на неопределенность, неясность и незавершенность. То обстоятельство, что в завершающей фразе текста сочетаются оба знака противоположной природы - восклицательный и многоточие - иконически демонстрирует коллизию противоположных структурных тенденций повести (стремлением к определенности и постоянно создаваемой в тексте неопределенностью).

\section{Заключение}

Центральный для сюжета мотив проникновения контрабандистов через границу приводит к семантизации геометрических и структурных понятий-таких, как предел, граница (в более абстрактном смысле) и сосуществование разных (принадлежащихразныммирам)элементов.Приэтомзначимостьсоответствующих категорий не ограничивается историей с контрабандистами, а захватывает весь мир произведения. Как мы видели, миру «Тамани» свойственна значимость границы на самых разных уровнях текста. Наряду с наличием четких противопоставлений, связанных с существованием границы, значима также и тенденция смазывания границы и создания неопределенности, причем вторая тенденция доминирует. Более того, такое смазывание не только противопоставлено четким дискретным элементам; в совокупности дискретная четкость и смазывание сами оказываются двумя разными вариантами чего-то более общего. В этом смысле получается еще одно отношение неопределенности. Мир произведения предстает как лишенный определенности и зыбкий, в котором уживаются качества, которые, казалось бы, должны противоречить друг другу. Причем указанные особенности пронизывают весь текст произведения, проявляясь на всех уровнях от отдельных слов до структуры как целого.

Возможно, указанная неопределенность и является самым существенным фактором, который создает интуитивно ощущаемую атмосферу таинственности этого произведения. Вторжение Печорина отчасти разрушает этот мир, что на первый взгляд должно сделать его более однозначным и потому понизить степень его таинственности. Однако существенно, что эта таинственность отнюдь не разрушается до конца, а в последнем подслушанном им разговоре она хотя бы отчасти компенсируется новыми элементами неопределенности.

По ходу анализа мы бегло упомянули о структурном «приеме», в котором семантизируется столь общее свойство как «нехватка». С более общей точки зрения, происходит семантизация повествовательной «нехватки». Ранее рассмотренный нами тип псевдооборванных текстов является частным случаем этого. Возникает вопрос о дальнейшем выявлении и классификации подобных текстов. Это явление нуждается в дальнейшем типологическом изучении, относящемся к общей поэтике.

\section{СПИСОК ЛИТЕРАТУРЫ}

Дурылин, С. «Герой нашего времени» М. Ю. Лермонтова. Пособие к изучению романа / С. Дурылин.- Москва: Учпедгиз, 1940.- 256 с. 
Жолковский, А. К. Семиотика «Тамани» / А. К. Жолковский // Сборник статей к 70-летию проф. Ю. М. Лотмана.- Тарту, 1992.- С. 248-256.

Заславский, О.Б. Герой, мир и структура текста: о «Тамани» М. Ю. Лермонтова / О. Б. Заславский // Wiener Slawistischer Almanach.- 2008. Band 61.- S. 69-83.

Заславский, О.Б. Структурные парадоксы русской литературы и поэтика псевдооборванного текста / О.Б. Заславский // Sign systems studies.- 2006.Vol. 34 (1).- P. 261-269.

Заславский, О.Б. Повесть Лермонтова «Штос»: идейная структура и сюжет / О. Б. Заславский // Известия РАН. Серия литературы и языка.- 2013. T. 72.- N 4.- C. 27-39.

Козубовская, Г. П. «Тамань» М. Ю. Лермонтова: балладный код. / Г. П. Козубовская. // Лермонтов. Pro et contra: в 2 т. Т. 2.- Санкт-Петербург: Изд-во Русской христианской гуманитарной академии, 2014.- С. 724-735.

Кривонос, В. Ш. «Тамань» Лермонтова: пространство, персонажи, сюжет / В.Ш. Кривонос // Известия Саратовского ун-та. Новая серия Сер. Филология. Журналистика.- 2019. Т. 19.- Вып. 1.- С. 41-44.

Лермонтов, М. Ю. Сочинения: в 6 т. Т. 6. Проза, письма / М. Ю. Лермонтов.Москва; Ленинград: Изд-во АН СССР, 1957.- 900 с.

Ломинадзе, С. В. Странствующий офицер (Заметки о «Тамани») / С. В. Ломинадзе // Ломинадзе С. В. О классиках и современниках.- Москва: Современник, 1989.- С. 319-348.

Мильчина, В. А. «Порода в женщинах» и «Юная Франция»: попытка комментария / В. А. Мильчина // Мир Лермонтова: коллективная монография.Санкт-Петербург: Скрипториум, 2015.- С. 560-571.

Савинков, С. В. Творческая логика Лермонтова / С.В. Савинков.Воронеж: Изд-во Воронежского государственного ун-та, 2004.- 288 с.

Савинков, С. В. «Тамань» М. Ю. Лермонтова: конфликт интерпретаций / С. В. Савинков, Е.В. Соколова // Известия Уральского федерального ун-та. Серия 2. Гуманитарные науки.- 2014. Т. 16.- № 4.- С. 46-50.

Силади, Ж. Тайны Печорина (семантическая структура образа героя в романе М. Ю. Лермонтова) / Ж. Силади // М. Ю. Лермонтов. Pro et contra.Санкт-Петербург: Изд-во Русской христианской гуманитарной академии, 2014.С. 616-629.

Силади, Ж. К поэтике и семантике Тамани Лермонтова / Ж. Силади // Studia russica Slavica tergestina- 2.- Trieste, 1994.- С. 21-33.

Славутин, Е.И. Структура сюжета / Е.И. Славутин, В.И. Пимонов.Москва: Флинта, 2018.- 172 с.

Топоров, В. Н. Имена / В. Н. Топоров // Мифы народов мира: Энциклопедия: в 2 т. Т. 1.- Москва: Советская Энциклопедия, 1987.- С. 508-510. 


\section{REFERENCES:}

Durylin, S. «Geroj nashego vremeni» M. Ju. Lermontova: Posobie k izucheniju romana / S. Durylin.-Moskva: Uchpedgiz, 1940.-256 s.

Kozubovskaja, G. P. «Taman'» M. Ju. Lermontova: balladnyj kod / G. P. Kozubovskaja // Lermontov. Pro et contra: v 2 t. T. 2.- Sankt-Peterburg: Izd-vo Russkoj hristianskoj gumanitarnoj akademii, 2014.-S. 724-735.

Krivonos, V. SH. «Taman» Lermontova: prostranstvo, personazhi, syuzhet / V. SH. Krivonos // Izvestiya Saratovskogo un-ta. Novaya seriya Ser. Filologiya. ZHurnalistika.-2019. T. 19.- Vyp. 1.- S. 41-44.

Lermontov, M. YU. Sochineniya: v 6 t. T. 6. Proza, pis'ma / M.YU. Lermontov.Moskva; Leningrad: Izd-vo AN SSSR, 1957.-900 s.

Lominadze, S. V. «"Stranstvuyushchij oficer" (Zametki o "Tamani”)» / S. V. Lominadze // Lominadze S. V. O klassikah i sovremennikah.- Moskva: Sovremennik, 1989.-S. 319-348.

Mil'china, V. A. «Poroda v zhenshchinah» i «YUnaya Franciya»: popytka kommentariya / V.A. Mil'china // Mir Lermontova: kollektivnaya monografiya.Sankt-Peterburg: Skriptorium, 2015.-S. 560-571.

Savinkov, S. V. Tvorcheskaya logika Lermontova / S. V. Savinkov.- Voronezh: Izd-vo Voronezhskogo gosudarstvennogo un-ta, 2004.-288 s.

Savinkov, S. V. «Taman'» M. YU. Lermontova: konflikt interpretacij / S. V. Savinkov, E. V. Sokolova // Izvestiya Ural'skogo federal'nogo un-ta. Seriya 2. Gumanitarnye nauki.-2014. T.16.- № 4.-S. 46-50.

Siladi, ZH. Tajny Pechorina (semanticheskaya struktura obraza geroya v romane M.YU. Lermontova) / ZH. Siladi // M. YU. Lermontov. Pro et contra.-Sankt-Peterburg: Izd-vo Russkoj hristianskoj gumanitarnoj akademii, 2014.-S. 616-629.

Siladi, ZH. K poetike i semantike Tamani Lermontova / ZH. Siladi // Studia russica Slavica tergestina- 2.- Trieste, 1994.- S. 21-33.

Slavutin, E. I. Struktura syuzheta / E. I. Slavutin, V. I. Pimonov.- Moskva: Flinta, 2018.- $172 \mathrm{~s}$.

Toporov, V. N. Imena / V. N. Toporov // Mify narodov mira: Enciklopediya: v 2 t. T. 1.-Moskva: Sov. Enciklopediya, 1987.-S. 508-510.

Zaslavskij, O. B. Geroj, mir i struktura teksta: o «Tamani» M. Ju. Lermontova / O. B. Zaslavskij // Wiener Slawistischer Almanach.-2008. Band 61.-S. 69-83.

Zaslavskij, O.B. Strukturnye paradoksy russkoj literatury i pojetika psevdooborvannogo teksta / O.B. Zaslavskij // Sign systems studies.- 2006.№ 34 (1).-S. 261-269.

Zaslavskij, O. B. Povest' Lermontova «Shtoss»: idejnaja struktura i sjuzhet / O. B. Zaslavskij // Izvestija RAN. Serija literatury i jazyka.-2013. T. 72.- N 4.S. 27-39.

Zholkovskij, A. K. Semiotika «Tamani» / A. K. Zholkovskij // Sbornik statej k 70-letiju prof. Ju. M. Lotmana.- Tartu, 1992.- S. 248-256. 